Acta arachnol., 41(2): 133-137, December 23, 1992

\title{
Three Species of the Genus Agroeca (Araneae: Clubionidae) from Japan, Including a New Species
}

\author{
Toshio HaYaSHI ${ }^{1)}$ \\ 林 俊夫 ${ }^{1)}$ ： 1 新種を含む日本産タンボグモ属（クモ目： \\ フクログモ科) の 3 種
}

\begin{abstract}
Three species of the genus Agroeca are reported from Japan: $A$. montana HaYASHI, 1986, A. coreana NAMKUNG, 1989, and $A$. kamurai sp. nov. Key to the Japanese species of the genus Agroeca is also given.
\end{abstract}

In 1986, the author described Agroeca montana HAYASHI which was the only known species of the genus from Japan. Recently, the author had an opportunity to examine some specimens of two species of Agroeca collected by Dr. Takahide Kamura.

After a careful examination, the author recognized that one of these species is Agroeca coreana NamKung, 1989, new to the fauna of Japan, and the other is new to science. Both the species will be described in this paper.

The holotype and allotype of the new species are deposited in the collection of the National Science Museum (Nat. Hist.), Tokyo.

The abbreviations used in this paper are the same as those explained in HAYASHI (1986).

\section{Genus Agroeca Westring, 1861}

A Japanese species of this genus was described by the author for the first time in 1986. Three species are known from Japan at present.

Characteristics of the genus are shown in HAYASHI (1986).

\section{Key to the Japanese Species}

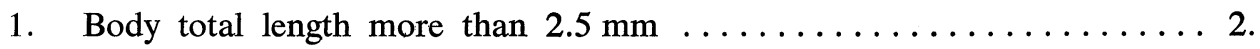

- Body total length less than $2.5 \mathrm{~mm} \ldots \ldots \ldots \ldots \ldots . . . .$. kamurai sp. nov.

2. Retrolateral tibial apophysis (RTA) of male palp bifurcated; median apophysis (MA) long and slender. (The female of coreana was not available.) ...................... coreana NAMkUng, 1989.

1) 414-1, Kiribara, Omama-machi, Yamada-gun, Gunma, 376-01 Japan

于376-01 群馬県山田郡大間々町桐原414-1

Accepted October 21, 1992 
- RTA not bifurcated; MA relatively broad; epigynal ducts relatively simple loops .................... montana HaYASHI, 1986.

\section{Agroeca montana HAYASHI, 1986}

(Figs. 1-4)

Agroeca montana HaYashi, 1986, Proc. Japn. Soc. syst. Zool., 33: 24, figs. 1-10.

Notes. This species was described by the author. He collected many specimens from the forest near the southeastern foot of Mt. Akagi.

It may be possible that the female of $A$. coreana described by NAMKUNG (1989) corresponds to that of $A$. montana.

Agroeca kamurai sp. nov.

(Figs. 5-8)

Measurements. Male/female (in mm). Body length 2.20/2.10, Cephalothorax length $1.10 / 1.15$, width $0.85 / 0.80$, abdomen length $1.02 / 1.34$, width $0.73 / 0.98$; lengths of legs as in Table 1. AME 0.04/0.07, ALE 0.06/0.12, PME 0.06/0.10, PLE 0.06/0.10, AME-AME 0.01/0.02, AME-ALE 0.01/ 0.04, PME-PME 0.06/0.12, PME-PLE 0.04/0.07, ALE-PLE 0.02/0.07, MOA front $0.09 / 0.20$, hind $0.19 / 0.37$, length $0.14 / 0.29$.

Table 1. Lengths of legs of Agroeca kamurai sp. nov. ( $\sigma^{\top /}$ 우; in mm).

\begin{tabular}{lcccccc}
\hline Leg & Femur & Patella & Tibia & Metatarsus & Tarsus & Total \\
\hline I & $0.80 / 0.80$ & $0.44 / 0.37$ & $0.68 / 0.66$ & $0.49 / 0.44$ & $0.51 / 0.44$ & $2.92 / 2.71$ \\
II & $0.85 / 0.68$ & $0.39 / 0.32$ & $0.54 / 0.54$ & $0.49 / 0.41$ & $0.51 / 0.41$ & $2.78 / 2.36$ \\
III & $0.59 / 0.61$ & $0.37 / 0.24$ & $0.49 / 0.37$ & $0.56 / 0.51$ & $0.49 / 0.44$ & $2.50 / 2.17$ \\
IV & $0.98 / 0.80$ & $0.46 / 0.46$ & $0.85 / 0.73$ & $0.98 / 0.78$ & $0.61 / 0.46$ & $3.88 / 3.23$
\end{tabular}

Chelicera normal with two teeth on pro- and retromargins of fang furrow. Metatarsi I and II with 2-2 ventral spines.

Male palp (Figs. 5-6). Tegulum with a sickle-shaped apophysis (Fig. 5), tibial apophysis long and slender and not bifurcated.

Female genitalia (Fig. 8). Epigynum with Y-shaped margin (Fig. 7), ducts $\Omega$-shaped curve.

Coloration and markings. Carapace light brown with dark brown stripe along the margin. Chelicera, maxillae, labium and sternum light brown. Legs light brown, becoming darker towards the distal ends. Abdomen greyish brown with chevrons.

Figs. 1-10 (on page 135). 1-4, Agroeca montana HAYASHI, 1986; 5-8, Agroeca kamurai sp. nov.; 9-10, Agroeca coreana NAMKUNG, 1989. — 1, 5, 9, male palp, ectal view; $2,6,10$, same, ventral view; 3,7 , epigynum, ventral view; 4,8 , genitalia, dorsal view. Scale: $0.25 \mathrm{~mm}$. 
Three Species of the Genus Agroeca
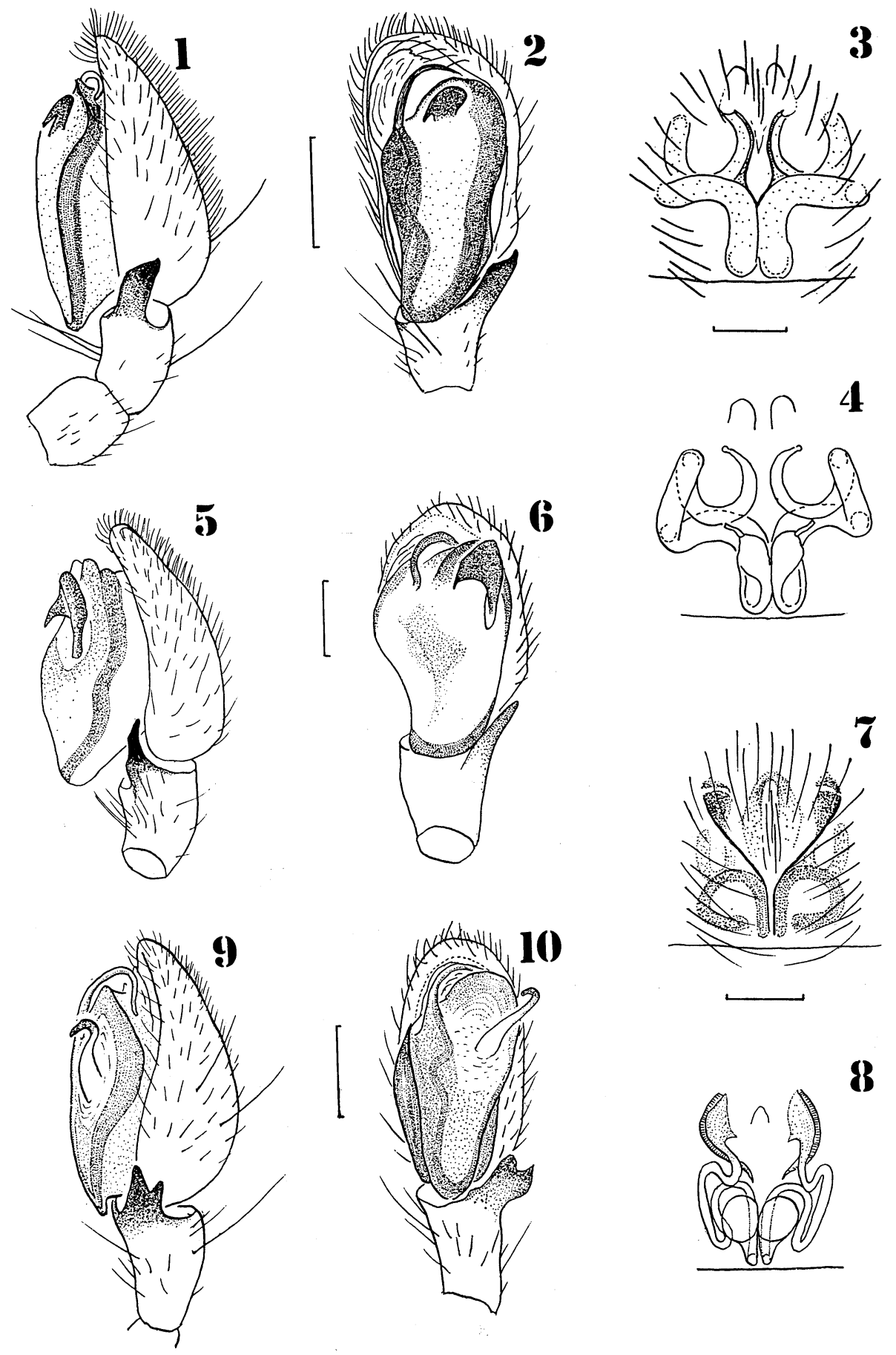
Type specimens. Holotype: ð, Kami-kamo, Kita-ku, Kyoto City, Kyoto Prefecture, 3-V-1983, T. KaMURA leg., allotype: ㅇ, same data as for the holotype. Paratype: ð, Fujioka City, Gunma Prefecture, 26-V-1985, T. HaYAshi leg.

Notes. This new species resembles A. montana HAYASHI, 1986, but is distinguished from the latter by the shapes of retorolateral apophysis on palpal tibia and copulatory ducts. This new species is smaller than $A$. coreana and $A$. montana, and its body length is less than $2.5 \mathrm{~mm}$.

Etymology. This species is named after the collector, Dr. T. Kamura.

\section{Agroeca coreana NAMKUNG, 1989}

(Figs. 9-10)

Agroeca coreana Namkung, 1989, Korean Arachnol., 5(1): 24, figs. 1-10.

Description based on the Japanese specimen. Measurements. Male (in mm). Body length 3.54; cephalothorax length 2.07, width 1.54; abdomen length 1.46, width 1.10; lengths of legs as in Table 2. AME 0.06. ALE 0.11. PME 0.11, PLE 0.12, AME-AME= PME-PLE 0.06, AME-ALE 0.02, PME-PME 0.10, ALE-PLE 0.04. MOA front 0.21, hind 0.31, length 0.22 .

Table 2. Lengths of legs of Agroeca coreana NAMkUNG, 1989 ( ðৃ; in mm).

\begin{tabular}{lcccccc}
\hline Leg & Femur & Patella & Tibia & Metatarsus & Tarsus & Total \\
I & 1.59 & 0.88 & 1.34 & 1.10 & 0.90 & 5.81 \\
II & 1.34 & 0.80 & 1.02 & 1.02 & 0.66 & 4.84 \\
III & 1.34 & 0.73 & 0.95 & 1.15 & 0.73 & 4.90 \\
IV & 1.90 & 0.85 & 1.59 & 2.02 & 0.98 & 7.34 \\
\hline
\end{tabular}

Chelicera normal; promargin of fang furrow with three teeth, retromargin with two teeth. Metatarsi I and II with 2-2 ventral spines, tibiae and metatarsi III and IV with 2-2-2 ventral spines.

Male palp (Figs. 9-10). Tegulum with a tibial apophysis long, fishhookshaped and bifurcated.

Coloration and markings. Carapace and chelicerae, maxillae, labium, sternum and legs light brown. Abdomen greyish brown.

Specimen examined. $10^{\Uparrow}$ : Kami-kamo, Kita-ku, Kyoto City, Kyoto Prefecture, 29-IX-1984, T. Kamura leg.

Remarks. Both sexes of $A$. coreana were described by NAMKUNG (1989) from Korea. The male from Japan well agrees with that of the figure made by NAMKUng. The figure of female by NAMKUNG strongly resembles that of $A$. montana HAYASHI, 1986, from Japan, but the opening part of epigynum of coreana seems wider than that of montana. This species is new to the fauna of Japan, on the basis of the male specimen. 


\section{Acknowledgements}

The author wishes to express his hearty thanks to Dr. Takeo YAGINUMA for his constant guidance to this study, and to Dr. Takahide Kamura, Otemon Gakuin University, for providing his precious materials.

摘 要

日本産タンボグモ属の 3 種, Agroeca coreana NAMKUNG, 1989 コウライタンボグモ (新称), A. montana HAYASHI, 1986 ミヤマタンボグモ, A. kamurai sp. nov. カムラ タンボグモ（新称）を報告した。また，日本産タンボグモ属の検索表を記した。

\section{References}

HaYASHI, T., 1986. A new Japanese spiders of the genus Agroeca (Araneae: Clubionidae). Proc. Japn. Soc. syst. Zool., (33): 23-28.

NamkunG, J., 1989. A new species of the genus Agroeca (Araneae: Clubionidae) from Korea. Korean Arachnol., 5: 23-28. 


\section{Instructions to Authors}

1. Acta Arachnologica is devoted to the study of arachnids and myriapods for the present.

2. The author should be a regular member having payed the membership fee of the current year or a honorary member of the Society. If necessary, some persons being not members can be included as co-authors.

3. Manuscripts are preferred in Japanese or English; those in German and French may be accepted in a reviewable case.

4. The original manuscript and two sets of complete xerox copies (including tables, figures or plates) should be submitted. All manuscripts should be addressed to the Managing Editor: Mr. Akio TAnikawa, Noba Senior High School, 1660, Noba-cho, Konan-ku, Yokohama, 233 Japan.

5. Manuscript selection is made by the Editorial Board.

6. Authors should prepare manuscripts with special care, referring to the current issue of the Journal.

7. Manuscripts should be typed double-spaced on one side of A4 or quarto paper leaving wide margins (at least $3 \mathrm{~cm}$ wide). Three manuscript pages equal about two printed pages (excluding tables, figures, plates, etc.). Available space for an article will be limited to 10 printed pages (including tables, figures, plates, etc.). For printing extra pages, additional cost must be borne by the author.

8. The manuscript should include the title, authors' names and complete addresses, abstract in English, text, references, a summary in Japanese (if possible) and, if necessary, tables, figures or plates with their explanations.

9. Tables, figures and plates should be numbered with a pencil in order of appearance with the authors' names. Figures or plates should be designed for full-column $(12 \mathrm{~cm}$ wide) printing at most. The reduction desired should be indicated with a blue pencil on the margin of each original figure or plate.

Places where tables and figures may be inserted should be marked on the margin of the manuscript. Explanation of figures and plates, typed double-spaced, should be set out on a separate sheet. Colored figures or plates are available at the expense of the author.

10. The running title (less than 50 characters) should be placed on the first page of the manuscript.

11. Reprints may be obtained at cost in blocks of 50 copies. The number of reprints required should be indicated on the first page of the manuscript.

12. A gally proof will be sent to the author. The corrected proof should be returned to the Managing Editor as soon as possible. 